\title{
Analisis Komparasi dan Determinan Sosial Demografi Terhadap Penggunaan Kontrasepsi Wanita Usia Subur (WUS) di Provinsi Nusa Tenggara Timur dan Jawa Timur
}

\author{
Dwi Cahyo Firmansyah ${ }^{1, \text { a) }}$, Fathin Nadillah ${ }^{2, \text { b) }}$, Firza Refo Adi Pratama ${ }^{3, c)}$, Ni Luh Putu \\ Yayang Septia Ningsih ${ }^{4, d)}$
}

\author{
${ }^{1}$ Politeknik Statistika STIS, Jl. Otto Iskandardinata No. 64C Jakarta 13330.
}

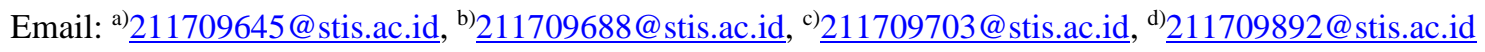

\begin{abstract}
Total Fertility Rate (TFR) is one indicator to see population growth in an area. While the high and low TFR in an area is always related to the contraceptive prevalence rate (CPR), which is a measure to see the percentage of contraceptive users in fertile age couples. In Indonesia, the province with the highest TFR is East Nusa Tenggara and the province with the lowest TFR is East Java. Therefore, researchers are interested in examining the social demographic factors that influence the use of contraceptive in the two provinces and then comparing the results. The analysis used is inferencing analysis with binary logistic regression and descriptive analysis. The results showed that social demographic factors that significantly influenced the use of contraception in women of childbearing age in East Nusa Tenggara were age, marital status, last education and the number of children ever born. While social demographic factors that had a significant effect on contraceptive use in women of childbearing age in East Java Province were age, marital status, last education, employment status and the number of children ever born. In general, most women of childbearing age who use contraception in the two provinces are women of childbearing aged 35-39 years, married, working in agriculture, having children more than two, the highest education attainment is primary school/equivalent. In other words there is no difference in characteristics between the two provinces with the highest and lowest TFRs.
\end{abstract}

Keywords: contraceptive, women of childbearing age, total fertility rate, binary logistic regression.

\begin{abstract}
Abstrak
Total Fertility Rate (TFR) merupakan salah satu indikator untuk melihat pertumbuhan penduduk di suatu daerah. Sedangkan tinggi rendahnya TFR disuatu daerah selalu berhubungan dengan Contraceptive Prevalence Rate (CPR), yaitu ukuran untuk melihat persentase pengguna alat kontrasepsi Pasangan Usia Subur (PUS). Di Indonesia, provinsi dengan TFR tertinggi yaitu Provinsi Nusa Tenggara Timur dan provinsi dengan TFR terendah yaitu Provinsi Jawa Timur. Oleh sebab itu, peneliti tertarik untuk meneliti mengenai faktor-faktor sosial demografi yang memengaruhi penggunaan alat kontrasepsi di kedua provinsi yang memiliki TFR tertinggi dan terendah tersebut lalu membandingkan hasilnya. Analisis yang digunakan yaitu analisis inferensia dengan regresi logistik biner dan analisis deskriptif. Hasil penelitian menunjukkan bahwa faktor-faktor sosial demografi yang berpengaruh signifikan terhadap penggunaan kontrasepsi pada wanita usia subur (WUS) di Provinsi Nusa Tenggara Timur adalah usia, status perkawinan, pendidikan terakhir dan jumlah anak yang pernah dilahirkan. Sedangkan faktor-faktor sosial demografi yang berpengaruh signifikan terhadap penggunaan kontrasepsi pada wanita usia subur (WUS)
\end{abstract}


di Provinsi Jawa Timur adalah usia, status perkawinan, pendidikan terakhir, status pekerjaan dan jumlah anak yang pernah dilahirkan. Secara umum, sebagian besar wanita usia subur (WUS) yang menggunakan alat kontrasepsi di kedua provinsi tersebut adalah wanita usia subur (WUS) yang berumur 35-39 tahun, berstatus kawin, bekerja disektor pertanian, memiliki anak lebih dari dua, serta pendidikan tertinggi yang ditamatkan adalah SD/sederajat. Dengan kata lain, tidak terdapat perbedaan karakteristik diantara kedua provinsi dengan TFR tertinggi dan terendah tersebut.

Kata-kata kunci: kontrasepsi, wanita usia subur, total fertility rate, Jawa Timur, Nusa Tenggara Timur, regresi logistik biner

\section{PENDAHULUAN}

Jumlah penduduk di Indonesia selalu mengalami kenaikan setiap tahunnya. Kenaikan jumlah penduduk ini salah satunya disebabkan oleh angka kelahiran yang tinggi (Silastri, 2017). Angka kelahiran dapat diukur melalui sebuah ukuran demografi yang disebut dengan Total Fertility Rate (TFR). TFR merupakan salah satu parameter demografi dan indikator kependudukan yang memengaruhi laju pertumbuhan penduduk. TFR adalah angka yang menggambarkan rata-rata jumlah anak yang akan dilahirkan oleh seorang wanita pada akhir masa reproduksinya (Kasto, 1995). Menurut data dari Badan Pusat Statistik, pada tahun 2017 angka TFR di Indonesia adalah sebesar 2.4. Angka ini memiliki makna yaitu rata-rata (WUS) di Indonesia memiliki 2 sampai 3 anak. Angka TFR di Indonesia dipengaruhi oleh penggunaan alat kontrasepsi. Menurut Freedman (1975), pemakaian kontrasepsi merupakan salah satu variabel yang memengaruhi tingkat fertilitas. Dalam kerangka pikir Bongaarts (1978) mengenai delapan intermediate variable yang memengaruhi fertilitas, kontrasepsi merupakan salah satu variabel yang memengaruhi fertilitas. Jadi, penggunaan alat kontrasepsi penduduk terutama pada wanita usia subur akan berpengaruh terhadap Total Ferlitity Rate (TFR) dimana TFR juga akan berpengaruh terhadap tinggi atau rendahnya pertumbuhan penduduk di suatu daerah.

Apabila dibandingkan dengan rata-rata TFR dunia, Total Fertility Rate (TFR) Indonesia sama dengan TFR dunia yaitu 2.4 (UN, 2017). Namun apabila dilihat di setiap provinsi di Indonesia, terdapat perbedaan angka TFR yang relatif jauh. Provinsi dengan TFR tertinggi adalah Provinsi Nusa Tenggara Timur dengan TFR 3.4 dan provinsi dengan TFR terendah adalah Provinsi Jawa Timur dengan TFR 2.1. Angka TFR tersebut berhubungan dengan penggunaan alat kontrasepsi wanita usia subur (WUS) di kedua provinsi tersebut.

Penggunaan Alat Kontrasepsi sebenarnya sudah digalakkan pemerintah sejak tahun 1970-an. Menurut UU Nomor 52 tahun 2009 tentang perkembangan kependudukan dan pembangunan keluarga, menyebutkan bahwa keluarga berencana sebagai upaya untuk mengatur kelahiran anak, jarak dan usia ideal melahirkan, mengatur kehamilan, melalui promosi, perlindungan, dan bantuan sesuai hak reproduksi untuk mewujudkan keluarga yang berkualitas. Tinggi rendahnya pemakaian kontrasepsi, berkaitan dengan angka keikutseraan program keluarga berencana (KB) wanita usia subur (WUS) umur 15-49 tahun di suatu daerah. Tindakan seorang wanita untuk memakai alat kontrasepsi tentu dipengaruhi berbagai faktor.

Hasil Penelitian Sukhan (2001) melaporkan faktor usia, jumlah anak, nilai anak bagi keluarga, pengetahuan, jarak lokasi ke pelayanan $\mathrm{KB}$, perilaku petugas merupakan faktor-faktor yang berhubungan dengan keikutsertaan pasangan usia subur dalam program KB. Syamsiah (2002) mengatakan bahwa faktor sosial budaya adalah semua faktor yang ada di masyarakat yang memengaruhi penerimaan suatu jenis alat kontarasepsi antara lain: sosio-ekonomi, demografi, psikososial, agama, dan pengetahuan.

Berdasarkan penelitian yang dilakuakan Kidayi (2015), wanita yang telah berdaya memiliki kecenderungan untuk memakai kontrasepsi modern. Hal ini terjadi karena permberdayaan perempuan dapat memengaruhi pemakaian kontrasepsi dengan menentukan egalitarianisme hubungan suami istri. Kesetaraaan istri dan suami dianggap terkait dengan kemungkinan mereka mengkomunikasikan tentang KB yang akan memengaruhi pemakaian kontrasepsi yang aman dan efektif.

Melihat latar belakang yang telah dipaparkan di atas, perlu dilakukan penelitian mengenai faktorfaktor sosial demografi (umur, status perkawinan, pendidikan, status pekerjaan, jumlah anak yang pernah dilahirkan) terhadap penggunaan alat kontrasepsi wanita usia subur terutama di Provinsi NTT 
yang memiliki TFR tertinggi dan di Provinsi Jawa Timur yang memiliki TFR terendah di Indonesia lalu membandingkan hasil yang didapatkan pada kedua provinsi tersebut untuk melihat perbedaan karakteristiknya.

\section{METODE}

\section{Ruang Lingkup Penelitian}

Penelitian ini mengamati tentang faktor-faktor yang memengaruhi wanita usia subur (WUS) dalam memilih menggunakan kontrasepsi atau tidak. Fokus penelitian ini mencakup dua Provinsi yakni Provinsi Nusa Tenggara Timur yang memiliki TFR paling tinggi di Indonesia pada tahun 2017 dan Provinsi Jawa Timur yang memiliki TFR paling rendah di Indonesia pada tahun 2017.

Variabel yang diteliti dalam penelitian ini dibedakan menjadi dua yaitu variabel tak bebas (variabel respon) dan variabel bebas. Penggunaan kontrasepsi pada wanita usia subur (WUS) yang terdiri dari menggunakan kontrasepsi dan tidak menggunakan kontrasepsi merupakan variabel respon dalam penelitian ini. Sedangkan faktor-faktor yang diduga memengaruhi penggunaan kontrasepsi pada wanita usia subur (WUS) antara lain faktor sosial demografi yang meliputi usia pada kelompok umur lima tahunan, tingkat pendidikan tertinggi yang ditamatkan, status perkawinan, jumlah anak yang pernah dilahirkan, dan status pekerjaan dari wanita usia subur (WUS) tersebut.

\section{Regresi Logistik Biner}

Regresi logistik biner adalah salah satu metode untuk mengetahui hubungan antar variabel bebas dan tak bebas, dimana variabel tak bebas berupa data nominal dengan dua kategorik, yang berarti kejadian yang akan dijelaskan mengikuti distribusi binomial. Selain itu metode analisis ini juga dapat memodelkan peluang terjadinya suatu kejadian. Dalam penelitian ini penulis ingin mengetahui faktorfaktor apa saja yang memengaruhi status penggunaan alat kontrasepsi (menggunakan atau tidak), serta memodelkan peluang seseorang akan menggunakan alat kontrasepsi untuk Provinsi NTT dan Jawa Timur.

Bentuk umum dari Model Regresi Logistik Biner adalah:

$$
L i=\ln \left(\frac{P i}{1-P i}\right)=\beta_{0}+\beta_{1} x_{1}+\ldots+\beta_{p} x_{p}
$$

Keterangan:

$L i=\operatorname{logit} P i$

$P i=$ peluang wanita usia subur dalam penggunakan kontrasepsi

$\beta_{0}=$ intercept

$\beta_{k}=$ koefisen regresi untuk setiap variabel, dimana $k=1,2, \ldots, p$

Parameter-parameter pada model regresi logistik diestimasi menggunakan metode Maximum Likelihood Estimator (MLE). Secara umum, metode MLE menghasilkan nilai parameter dengan cara memaksimumkan fungsi likelihood dari nilai peluang pada kelompok data yang diamati. Fungsi ini menyatakan peluang dari data yang diamati sebagai suatu fungsi dari parameter yang tidak diketahui (Hosmer \& Lemeshow, 2000).

Dalam menganalisis data menggunakan metode regresi logistik biner, perlu dilakukan pengujian parameter, baik secara simultan maupun parsial. Pengujian parameter secara simultan menggunakan uji Likelihood Ratio untuk mengetahui pengaruh variabel penjelas terhadap variabel respons secara simultan atau bersama-sama. Hipotesis yang digunakan untuk uji ini adalah:

$$
H_{0}: \beta_{1}=\beta_{2}=\ldots=\beta_{p}=0
$$

(tidak ada pengaruh signifikan dari variabel-variabel penjelas terhadap variabel respons secara simultan) 
$H_{1}$ : minimal terdapat satu $\beta_{j} \neq 0$

(Minimal terdapat satu variabel penjelas yang berpengaruh signifikan terhadap variabel respons)

dengan $\mathrm{j}=1,2, \ldots, \mathrm{p}$ dan $\mathrm{p}$ merupakan banyaknya variabel penjelas.

Sedangkan uji parameter parsial dapat menggunakan uji Wald untuk mengetahui pengaruh variabel penjelas terhadap variabel respons dalam model secara parsial. Hipotesis yang digunakan dalam uji ini adalah:

$$
H_{0}: \beta_{j}=0
$$

(tidak ada pengaruh signifikan dari variabel penjelas ke- $j$ terhadap variabel respons)

$$
H_{1}: \beta_{j} \neq 0
$$

(terdapat pengaruh signifikan dari variabel penjelas ke-j terhadap variabel respons)

dengan $\mathrm{j}=1,2, \ldots, \mathrm{p}$ dan $\mathrm{p}$ merupakan banyaknya variabel penjelas.

\section{HASIL DAN PEMBAHASAN}

\section{Gambaran Umum Status Penggunaan Kontrasepsi pada Wanita Usia Subur}

Status penggunaan alat kontrasepsi pada wanita usia subur (WUS) di Provinsi Nusa Tenggara Timur dan Jawa Timur pada tahun 2017 ditunjukkan pada Gambar 1.

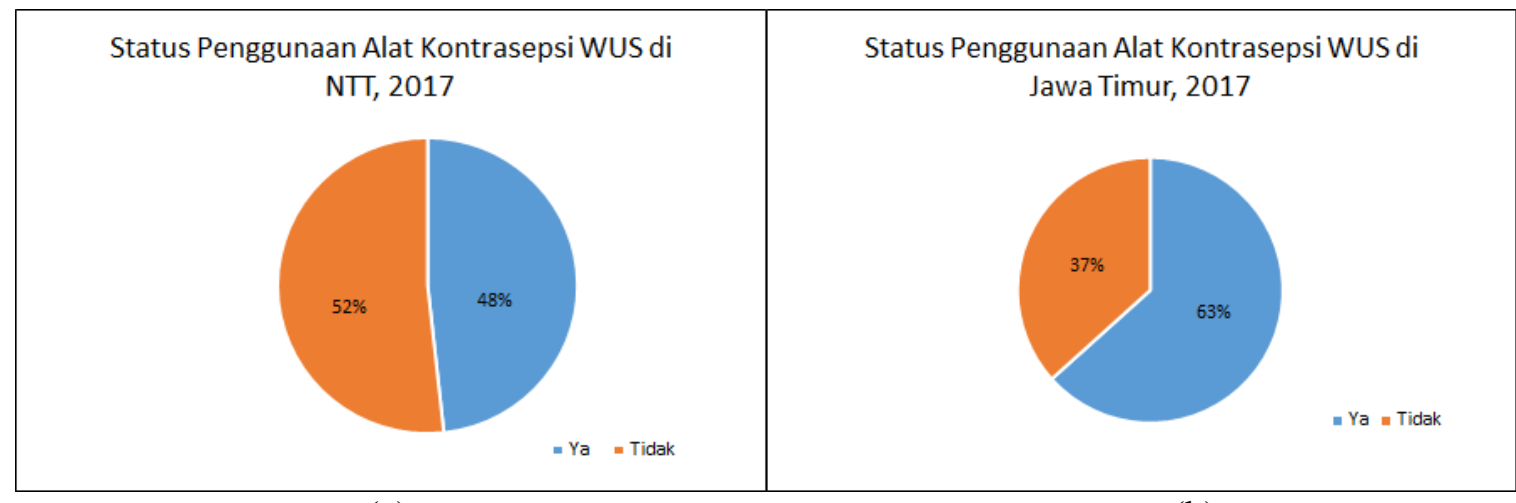

(a)

(b)

GAMBAR 1. Status penggunaan alat kontrasepsi pada wanita usia subur (WUS) di Provinsi Nusa Tenggara Timur (a) dan Provinsi Jawa Timur (b) pada tahun 2017.

Berdasarkan Gambar 1, Proporsi wanita usia subur (WUS) yang menggunakan alat kontrasepsi di Provinsi Jawa Timur lebih tinggi dibandingkan dengan Provinsi NTT, di Provinsi Jawa Timur WUS yang menggunakan alat kontrasepsi sebanyak 63.4\%, sedangkan di Provinsi NTT WUS yang menggunakan alat kontrasepsi sebanyak $48.27 \%$. 


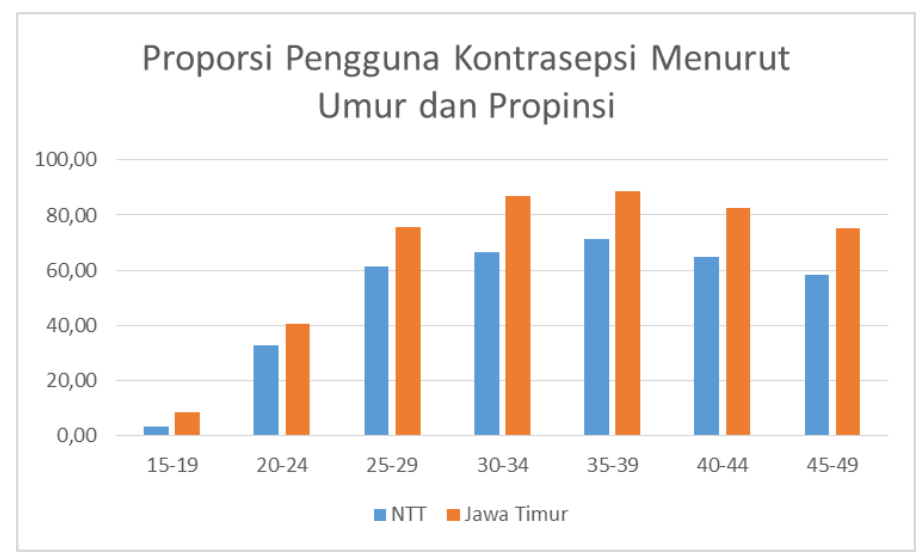

GAMBAR 2. Proporsi pengguna kontrasepsi menurut kelompok umur dan provinsi

Gambar 2 menunjukkan proporsi wanita usia subur (WUS) yang menggunakan kontrasepsi menurut kelompok umur dan provinsi. Berdasarkan kelompok umur WUS yang ditunjukkan oleh Gambar 2, baik di Nusa Tenggara Timur maupun di Jawa Timur, proporsi tertinggi wanita yang pernah menggunakan alat kontrasepsi terletak pada WUS dengan kelompok umur (35-39). Hal ini disebabkan kelompok umur tersebut (35-39 tahun) merupakan kelompok yang berpotensi tinggi untuk mengalami kehamilan yang ideal. WUS pada kelompok umur tersebut sudah memiliki jumlah anak sesuai yang diinginkan, sehingga mereka menggunakan alat kontrasepsi untuk mengendalikan kelahiran. Pengguna alat kontrasepsi terendah di Provinsi NTT dan Jawa Timur terdapat pada kelompok umur 15-19. Hal ini disebabkan pada kelompok umur tersebut kebanyakan belum pernah mengalami perkawinan.

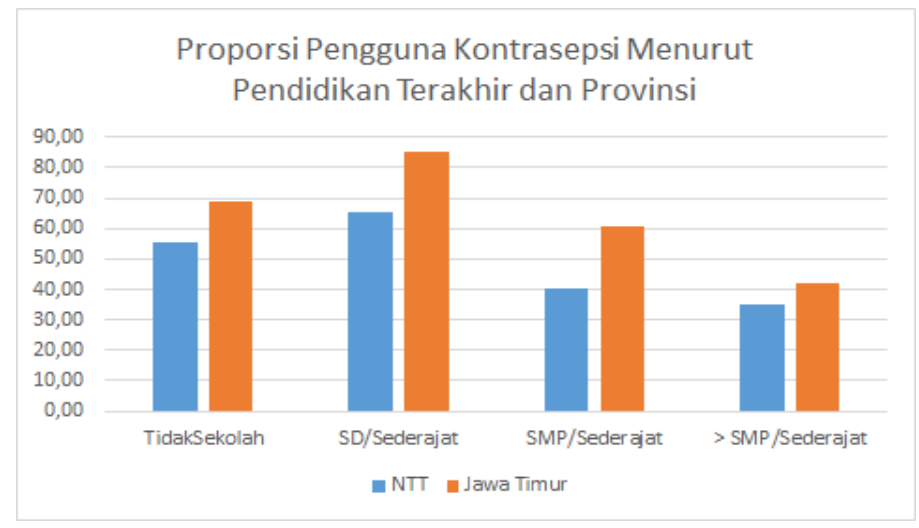

GAMBAR 3. Proporsi pengguna kontrasepsi menurut pendidikan terakhir dan provinsi.

Gambar 3 menunjukkan proporsi wanita usia subur (WUS) yang menggunakan kontrasepsi menurut pendidikan terakhir dan provinsi. Berdasarkan tingkat pendidikan terakhir WUS yang ditunjukkan oleh gambar 3, baik di Nusa Tenggara Timur maupun di Jawa Timur, proporsi tertinggi wanita yang pernah menggunakan alat kontrasepsi terletak pada kelompok dengan pendidikan terakhir $\mathrm{SD} /$ Sederajat. Sedangkan proporsi terendah yang menggunakan alat kontrasepsi terletak pada kelompok wanita dengan pendidikan di atas SMP/Sederajat. 


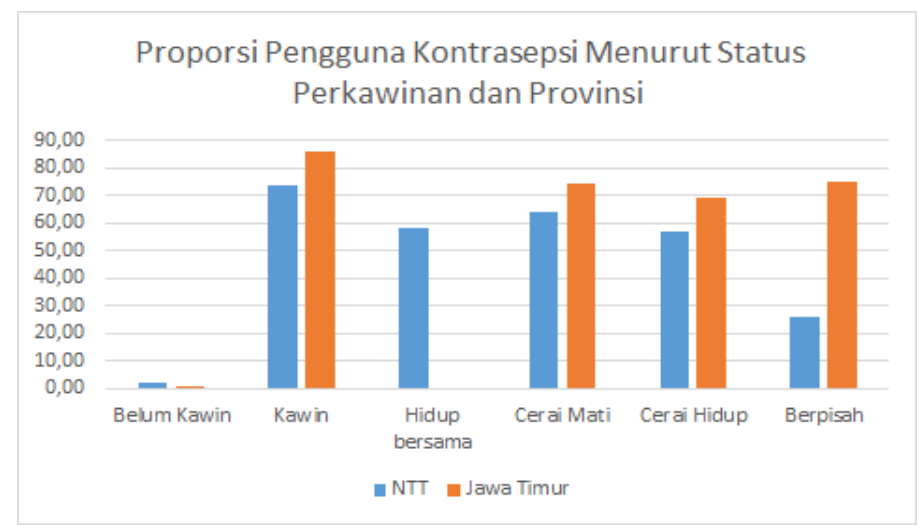

GAMBAR 4. Proporsi pengguna kontrasepsi menurut status perkawinan terakhir dan provinsi.

Gambar 4 menunjukkan proporsi wanita usia subur (WUS) yang menggunakan kontrasepsi menurut status perkawinan terakhir dan provinsi. Berdasarkan status perkawinan WUS yang ditunjukkan oleh Gambar 4, baik di Nusa Tenggara Timur maupun di Jawa Timur, proporsi tertinggi wanita yang pernah menggunakan alat kontrasepsi terletak pada kelompok dengan status kawin, sedangkan proporsi terendah yang menggunakan alat kontrasepsi terletak pada kelompok dengan status belum kawin.

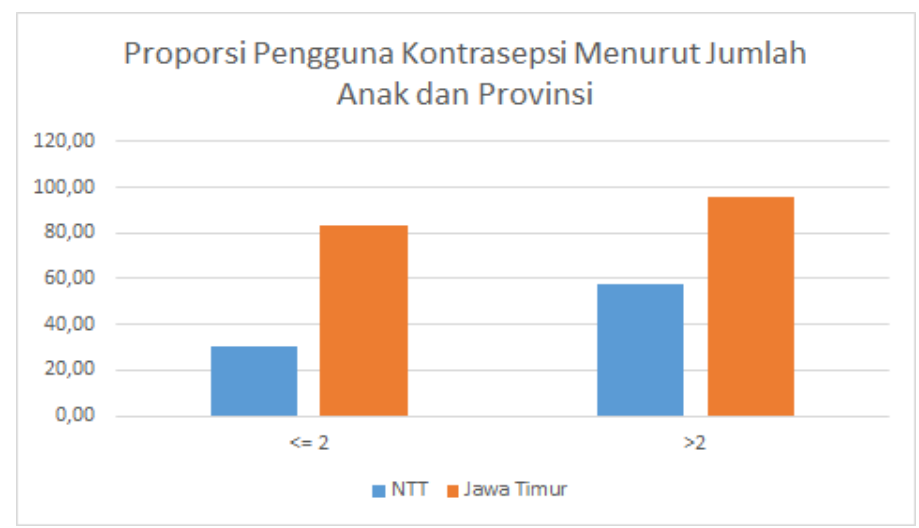

GAMBAR 5. Proporsi pengguna kontrasepsi menurut jumlah anak yang pernah dilahirkan dan provinsi.

Gambar 5 menunjukkan proporsi wanita usia subur (WUS) yang menggunakan kontrasepsi menurut jumlah anak yang pernah dilahirkan dan provinsi. Berdasarkan jumlah anak yang pernah dilahirkan yang ditunjukkan oleh Gambar 5, baik di Nusa Tenggara Timur maupun di Jawa Timur, proporsi tertinggi wanita yang pernah menggunakan alat kontrasepsi terletak pada kelompok dengan jumlah anak lebih dari dua. Hal ini menunjukkan bahwa ketika seorang WUS sudah memiliki lebih dari dua orang anak, maka ia akan cenderung membatasi jumlah anak, sejalan dengan program Keluarga Berencana yang tengah digalakkan oleh pemerintah dengan slogan dua anak cukup. 


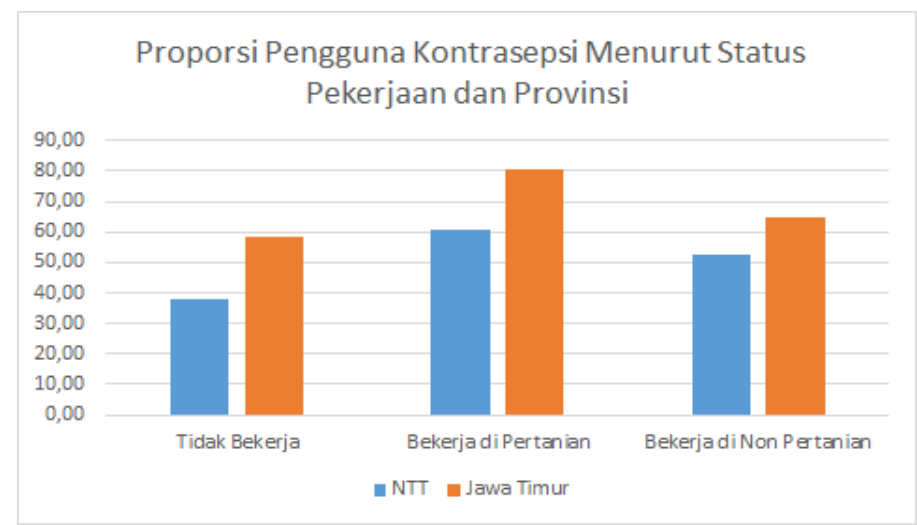

GAMBAR 6. Proporsi pengguna kontrasepsi menurut status pekerjaan dan provinsi.

Gambar 6 menunjukkan proporsi wanita usia subur (WUS) yang menggunakan kontrasepsi menurut status pekerjaan dan provinsi. Berdasarkan status pekerjaan yang ditunjukkan oleh Gambar 6, baik di Nusa Tenggara Timur maupun di Jawa Timur, proporsi tertinggi wanita yang pernah menggunakan alat kontrasepsi terletak pada kelompok dengan status bekerja di pertanian. Hal ini dapat disebabkan oleh cakupan objek dalam penelitian ini adalah seluruh WUS, tanpa membedakan status perkawinan. Jika diamati pada WUS dengan status kawin saja, proporsi pengguna kontrasepsi terbanyak adalah WUS dengan status Tidak bekerja.

\section{Variabel-variabel yang Memengaruhi Pemakaian Kontrasepsi Wanita Usia Subur (WUS)}

Untuk mengetahui apakah variabel independen yang meliputi usia pada kelompok, tingkat pendidikan tertinggi yang ditamatkan, status perkawinan, jumlah anak yang pernah dilahirkan, dan status pekerjaan dari wanita usia subur (WUS) tersebut secara bersama-sama berpengaruh signifikan terhadap variabel respon (penggunaan kontrasepsi pada wanita usia subur), maka dilakukan analisis menggunakan regresi logistik biner baik dengan pengujian secara simultan dan uji parsialnya.

Pengujian parameter simultan dilakukan dengan melihat hasil output dari pemrosesan data penelitian menggunakan bantuan program IBM SPSS Statistics 24, yaitu nilai statistik uji $G$ yang dapat dilihat pada tabel Omnibus Tests of Model Coeffiecients.

Berdasarkan tabel tersebut dapat dilihat bahwa nilai statistik uji $G$ untuk Provinsi Nusa Tenggara Timur adalah sebesar 1247.445 dengan nilai p-value sebesar 0.000. Dengan taraf signifikansi 5\%, maka keputusan yang diambil adalah menolak $\mathrm{H}_{0}$. Hal tersebut berarti bahwa minimal terdapat satu variabel bebas yang berpengaruh secara signifikan terhadap penggunaan kontrasepsi pada wanita usia subur (WUS) di Provinsi Nusa Tenggara Timur.

Sedangkan untuk Provinsi Jawa Timur, nilai statistik uji G adalah sebesar 2810.991 dengan nilai pvalue sebesar 0.000. Dengan taraf signifikansi 5\%, maka keputusan yang diambil adalah menolak $\mathrm{H}_{0}$. Hal tersebut berarti bahwa minimal terdapat satu variabel bebas yang berpengaruh secara signifikan terhadap penggunaan kontrasepsi pada wanita usia subur (WUS) di Provinsi Jawa Timur.

Setelah mengetahui bahwa terdapat minimal satu variabel bebas yang berpengaruh secara signifikan terhadap penggunaan kontrasepsi pada wanita usia subur (WUS) melalui uji parameter simultan, maka selanjutnya dapat dilakukan uji parameter parsial untuk mengetahui variabel bebas mana yang berpengaruh secara signifikan terhadap penggunaan kontrasepsi pada wanita usia subur (WUS).

Berdasarkan hasil pengujian parameter secara parsial, diketahui bahwa semua variabel yaitu usia pada kelompok umur, tingkat pendidikan tertinggi yang ditamatkan, status perkawinan, jumlah anak yang pernah dilahirkan, dan status pekerjaan dari wanita usia subur (WUS) tersebut berpengaruh secara signifikan terhadap penggunaan kontrasepsi pada wanita usia subur (WUS) di Provinsi Jawa Timur pada taraf signifikansi 0.05. Sedangkan di Provinsi Nusa Tenggara Timur, variabel status pekerjaan dari wanita usia subur (WUS) tidak berpengaruh secara signifikan di dalam model sehingga variabel tersebut dieliminasi. 
Selanjutnya perlu dilakukan Uji Goodness of Fit untuk mengetahui apakah suatu model sudah sesuai atau tidak dalam menjelaskan penggunaan kontrasepsi pada wanita usia subur (WUS). Uji ini menggunakan metode Hosmer dan Lemeshow Test. Hasil pengujiannya menunjukkan nilai p-value 0.486 untuk Provinsi Nusa Tenggara Timur dan 0.568 untuk Provinsi Jawa Timur. Nilai p-value tersebut lebih besar dari tingkat signifikansi yang telah ditetapkan yaitu 0.05 sehingga keputusan yang diambil adalah gagal menolak Ho. Keputusan tersebut bermakna model sesuai (fit) dalam menjelaskan penggunaan kontrasepsi pada wanita usia subur (WUS) di kedua provinsi tersebut dan layak untuk dilakukan analisis selanjutnya.

Berdasarkan hasil yang telah terbentuk, dapat diketahui kecenderungan masing-masing variabel penjelas terhadap variabel respon yaitu penggunaan kontrasepsi pada wanita usia subur (WUS). Nilai odds ratio dapat dilihat dari nilai $\exp \left(\beta_{k}\right)$ sedangkan nilai $\beta_{k}$ adalah nilai koefisien dari masingmasing variabel.

TABEL 1. Signifikasi parameter logistik biner untuk Provinsi Nusa Tenggara Timur

\begin{tabular}{|c|c|c|c|c|}
\hline Nama Variabel & Kategori & $\widehat{\boldsymbol{\beta}}$ & p-value & $\operatorname{Exp}(\widehat{\beta})$ \\
\hline Konstanta & & -3.539 & 0.000 & 0.029 \\
\hline \multirow{7}{*}{ Kelompok Umur } & $1=15-19$ & 0.215 & 0.599 & 1.240 \\
\hline & $2=20-24$ & 1.243 & 0.000 & 3.465 \\
\hline & $3=25-29$ & 1.878 & 0.000 & 6.543 \\
\hline & $4=30-34$ & 1.117 & 0.000 & 3.057 \\
\hline & $5=35-39$ & 1.087 & 0.000 & 2.964 \\
\hline & $6=40-44$ & 0.446 & 0.049 & 1.562 \\
\hline & $7=45-49 *$ & - & 0.000 & - \\
\hline \multirow{4}{*}{ Tingkat pendidikan tertinggi yang ditamatkan } & $0=$ Tidak Sekolah $*$ & - & 0.040 & - \\
\hline & $1=\mathrm{SD} /$ sederajat & 0.720 & 0.008 & 2.054 \\
\hline & $2=\mathrm{SMP} /$ sederajat & 0.571 & 0.038 & 1.769 \\
\hline & $3=>\mathrm{SMP} /$ sederajat & 0.425 & 0.159 & 1.530 \\
\hline \multirow{6}{*}{ Status Perkawinan } & $0=$ Belum Kawin $*$ & - & 0.000 & - \\
\hline & $1=$ Kawin & 4.008 & 0.000 & 55.010 \\
\hline & $2=$ Hidup bersama & 3.637 & 0.000 & 37.974 \\
\hline & $3=$ Cerai Mati & 3.460 & 0.000 & 31.822 \\
\hline & $4=$ Cerai Hidup & 3.686 & 0.000 & 39.887 \\
\hline & $5=$ Berpisah & 1.959 & 0.000 & 7.091 \\
\hline \multirow{2}{*}{ Jumlah Anak Yang Pernah Dilahirkan } & $0=>2 *$ & - & - & - \\
\hline & $1=\leq 2$ & -1.735 & 0.000 & 0.176 \\
\hline
\end{tabular}


Persamaan dugaan yang terbentuk adalah:

$$
\begin{aligned}
& \hat{L}_{i}=\ln \left(\frac{P i}{1-P i}\right)=-3.539+0.215 D_{11}+1.243 D_{12}^{*}+1.878 D_{13}^{*}+1.117 D_{14}^{*}+1.087 D_{15}^{*}+0.446 D_{16}^{*} \\
& +0.720 D_{21}^{*}+0.571 D_{22}^{*}+0.425 D_{23}+4.008 D_{31}^{*}+3.637 D_{32}^{*}+3.460 D_{33}^{*}+3.686 D_{34}^{*}+1.959 D_{35}^{*} \\
& -1.735 D_{4}^{*}
\end{aligned}
$$

\begin{tabular}{|c|c|c|c|c|}
\hline Nama Variabel & Kategori & $\widehat{\beta}$ & p-value & $\operatorname{Exp}(\hat{\beta})$ \\
\hline Konstanta & & -4.148 & 0.000 & 0.016 \\
\hline \multirow{7}{*}{ Kelompok Umur } & $1=15-19$ & -0.348 & 0.291 & 0.706 \\
\hline & $2=20-24$ & 0.291 & 0.192 & 1.338 \\
\hline & $3=25-29$ & 0.871 & 0.000 & 2.390 \\
\hline & $4=30-34$ & 1.327 & 0.000 & 3.768 \\
\hline & $5=35-39$ & 1.056 & 0.000 & 2.876 \\
\hline & $6=40-44$ & 0.518 & 0.018 & 1.678 \\
\hline & $7=45-49 *$ & - & 0.000 & - \\
\hline \multirow{4}{*}{ Tingkat pendidikan tertinggi yang ditamatkan } & $0=$ Tidak Sekolah $*$ & - & 0.000 & - \\
\hline & $1=\mathrm{SD} /$ sederajat & 0.930 & 0.009 & 2.534 \\
\hline & $2=\mathrm{SMP} /$ sederajat & 0.732 & 0.039 & 2.079 \\
\hline & $3=>\mathrm{SMP} /$ sederajat & -0.295 & 0.430 & 0.745 \\
\hline \multirow{6}{*}{ Status Perkawinan } & $0=$ Belum Kawin $*$ & - & 0.000 & - \\
\hline & $1=$ Kawin & 6.546 & 0.000 & 696.397 \\
\hline & $2=$ Hidup bersama & - & - & - \\
\hline & $3=$ Cerai Mati & 5.924 & 0.000 & 373.961 \\
\hline & $4=$ Cerai Hidup & 5.593 & 0.000 & 268.553 \\
\hline & $5=$ Berpisah & 6.551 & 0.000 & 700.145 \\
\hline \multirow{2}{*}{ Jumlah Anak Yang Pernah Dilahirkan } & $0=>2 *$ & - & - & - \\
\hline & $1=\leq 2$ & -1.767 & 0.000 & 0.171 \\
\hline \multirow{3}{*}{ Status Pekerjaan } & $0=$ Tidak Bekerja $*$ & - & 0.009 & - \\
\hline & $1=$ Bekerja di Pertanian & -0.463 & 0.044 & 0.629 \\
\hline & $2=$ Bekerja di Non Pertanian & -0.430 & 0.003 & 0.651 \\
\hline
\end{tabular}

TABEL 2. Signifikasi parameter regresi logistik biner untuk Provinsi Jawa Timur

Persamaan dugaan yang terbentuk adalah:

$$
\begin{aligned}
& \hat{L}_{i}=\ln \left(\frac{P i}{1-P i}\right)=-4.148+0.348 D_{11}+0.291 D_{12}+0.871 D_{13}^{*}+1.327 D_{14}^{*}+1.056 D_{15}^{*}+0.518 D_{16}^{*} \\
& +0.930 D_{21}^{*}+0.732 D_{22}^{*}+0.295 D_{23}+6.546 D_{31}^{*}+5.924 D_{33}^{*}+5.593 D_{34}^{*}+6.551 D_{35}^{*}-1.767 D_{4}^{*} \\
& -0.463 D_{51}^{*}-0.430 D_{52}^{*}
\end{aligned}
$$

\section{Interpretasi odd ratio untuk setiap variabel}

\section{Nilai intersep}

Nilai odds ratio pada intersep untuk Provinsi Nusa Tenggara Timur dan Jawa Timur masingmasing adalah sebesar 0.029 dan 0.016. Artinya, wanita usia subur (WUS) kelompok umur 45-49 tahun yang tidak sekolah dengan status perkawinan belum kawin dan jumlah anak yang pernah dilahirkan adalah lebih dari dua anak serta tidak bekerja memiliki kecenderungan masing-masing 0.029 dan 0.016 kali lebih kecil untuk menggunakan kontrasepsi di kedua provinsi tersebut.

\section{Umur}

Nilai odds ratio variabel usia wanita usia subur (WUS) kelompok umur adalah:

a. Pada kelompok umur 15-19 tahun, nilai odds ratio untuk Provinsi Nusa Tenggara Timur dan Jawa

Timur masing-masing adalah 1.240 dan 0.706. Artinya, wanita usia subur (WUS) yang berumur 
15-19 tahun di Provinsi Nusa Tenggara Timur memiliki kecenderungan 1.240 kali lebih besar untuk menggunakan kontrasepsi dibandingkan WUS yang berumur 45-49 tahun dengan nilai variabel lain konstan. Sedangkan wanita usia subur yang berumur 15-19 tahun di Provinsi Jawa Timur memiliki kecenderungan 0.706 kali lebih kecil untuk menggunakan kontrasepsi dibandingkan WUS yang berumur 45-49 tahun dengan nilai variabel lain konstan.

b. Pada kelompok umur 20-24 tahun, nilai odds ratio untuk Provinsi Nusa Tenggara Timur dan Jawa Timur masing-masing adalah 3.465 dan 1.338. Artinya, wanita usia subur (WUS) yang berumur 20-24 tahun di Provinsi Nusa Tenggara Timur memiliki kecenderungan 3.465 kali lebih besar untuk menggunakan kontrasepsi dibandingkan WUS yang berumur 45-49 tahun dengan nilai variabel lain konstan. Sedangkan wanita usia subur yang berumur 20-24 tahun di Provinsi Jawa Timur memiliki kecenderungan 1.338 kali lebih besar untuk menggunakan kontrasepsi dibandingkan WUS yang berumur 45-49 tahun dengan nilai variabel lain konstan.

c. Pada kelompok umur 25-29 tahun, nilai odds ratio untuk Provinsi Nusa Tenggara Timur dan Jawa Timur masing-masing adalah 6.543 dan 2.390. Artinya, wanita usia subur (WUS) yang berumur 25-29 tahun di Provinsi Nusa Tenggara Timur memiliki kecenderungan 6.543 kali lebih besar untuk menggunakan kontrasepsi dibandingkan WUS yang berumur 45-49 tahun dengan nilai variabel lain konstan. Sedangkan wanita usia subur yang berumur 25-29 tahun di Provinsi Jawa Timur memiliki kecenderungan 2.390 kali lebih besar untuk menggunakan kontrasepsi dibandingkan WUS yang berumur 45-49 tahun dengan nilai variabel lain konstan.

d. Pada kelompok umur 30-34 tahun, nilai odds ratio untuk Provinsi Nusa Tenggara Timur dan Jawa Timur masing-masing adalah 3.057 dan 3.768. Artinya, wanita usia subur (WUS) yang berumur 30-34 tahun di Provinsi Nusa Tenggara Timur memiliki kecenderungan 3.057 kali lebih besar untuk menggunakan kontrasepsi dibandingkan WUS yang berumur 45-49 tahun dengan nilai variabel lain konstan. Sedangkan wanita usia subur yang berumur 30-34 tahun di Provinsi Jawa Timur memiliki kecenderungan 3.768 kali lebih besar untuk menggunakan kontrasepsi dibandingkan WUS yang berumur 45-49 tahun dengan nilai variabel lain konstan.

e. Pada kelompok umur 35-39 tahun, nilai odds ratio untuk Provinsi Nusa Tenggara Timur dan Jawa Timur masing-masing adalah 2.964 dan 2.876. Artinya, wanita usia subur (WUS) yang berumur 35-39 tahun di Provinsi Nusa Tenggara Timur memiliki kecenderungan 2.964 kali lebih besar untuk menggunakan kontrasepsi dibandingkan WUS yang berumur 45-49 tahun dengan nilai variabel lain konstan. Sedangkan wanita usia subur yang berumur 35-39 tahun di Provinsi Jawa Timur memiliki kecenderungan 2.876 kali lebih besar untuk menggunakan kontrasepsi dibandingkan WUS yang berumur 45-49 tahun dengan nilai variabel lain konstan.

f. Pada kelompok umur 40-44 tahun, nilai odds ratio untuk Provinsi Nusa Tenggara Timur dan Jawa Timur masing-masing adalah 1.562 dan 1.678. Artinya, wanita usia subur (WUS) yang berumur 40-44 tahun di Provinsi Nusa Tenggara Timur memiliki kecenderungan 1.562 kali lebih besar untuk menggunakan kontrasepsi dibandingkan WUS yang berumur 45-49 tahun dengan nilai variabel lain konstan. Sedangkan wanita usia subur yang berumur 40-44 tahun di Provinsi Jawa Timur memiliki kecenderungan 1.678 kali lebih besar untuk menggunakan kontrasepsi dibandingkan WUS yang berumur 45-49 tahun dengan nilai variabel lain konstan.

Hasil penelitian ini sejalan dengan penelitian yang dilakukan oleh Asiimwe (2013), yang menyatakan bahwa wanita yang lebih muda akan cenderung memiliki keinginan untuk memiliki anak dibandingkan wanita pada kelompok umur yang lebih tua.

\section{Tingkat Pendidikan Tertinggi yang ditamatkan}

Nilai odds ratio variabel tingkat pendidikan tertinggi yang ditamatkan adalah:

a. Pada kategori SD/sederajat, nilai odds ratio untuk Provinsi Nusa Tenggara Timur dan Jawa Timur masing-masing adalah 2.054 dan 2.534. Artinya, wanita usia subur (WUS) yang pendidikan tertingginya adalah SD/sederajat di Provinsi Nusa Tenggara Timur memiliki kecenderungan 2.054 kali lebih besar untuk menggunakan kontrasepsi dibandingkan dengan WUS yang tidak sekolah dengan nilai variabel lain konstan. Sedangkan wanita usia subur (WUS) yang pendidikan tertingginya adalah SD/sederajat di Provinsi Jawa Timur memiliki 
kecenderungan 2.534 kali lebih besar untuk menggunakan kontrasepsi dibandingkan dengan WUS yang tidak sekolah dengan nilai variabel lain konstan.

b. Pada kategori SMP/sederajat, nilai odds ratio untuk Provinsi Nusa Tenggara Timur dan Jawa Timur masing-masing adalah 1.769 dan 2.079. Artinya, wanita usia subur (WUS) yang pendidikan tertingginya adalah SMP/sederajat di Provinsi Nusa Tenggara Timur memiliki kecenderungan 1.769 kali lebih besar untuk menggunakan kontrasepsi dibandingkan dengan WUS yang tidak sekolah dengan nilai variabel lain konstan. Sedangkan wanita usia subur (WUS) yang pendidikan tertingginya adalah SMP/sederajat di Provinsi Jawa Timur memiliki kecenderungan 2.079 kali lebih besar untuk menggunakan kontrasepsi dibandingkan dengan WUS yang tidak sekolah dengan nilai variabel lain konstan.

c. Pada kategori lebih tinggi dari SMP/sederajat, nilai odds ratio untuk Provinsi Nusa Tenggara Timur dan Jawa Timur masing-masing adalah 1.530 dan 0.745 . Artinya, wanita usia subur (WUS) yang pendidikan tertingginya adalah lebih tinggi dari SMP/sederajat di Provinsi Nusa Tenggara Timur memiliki kecenderungan 1.530 kali lebih besar untuk menggunakan kontrasepsi dibandingkan dengan WUS yang tidak sekolah dengan nilai variabel lain konstan. Sedangkan wanita usia subur (WUS) yang pendidikan tertingginya adalah lebih tinggi dari SMP/sederajat di Provinsi Jawa Timur memiliki kecenderungan 0.745 kali lebih kecil untuk menggunakan kontrasepsi dibandingkan dengan WUS yang tidak sekolah dengan nilai variabel lain konstan.

\section{Status Perkawinan}

Nilai odds ratio variabel status perkawinan adalah:

a. Pada kategori kawin, nilai odds ratio untuk Provinsi Nusa Tenggara Timur dan Jawa Timur masing-masing adalah 55.010 dan 696.397. Artinya, wanita usia subur (WUS) yang berstatus kawin di Provinsi Nusa Tenggara Timur memiliki kecenderungan 55.010 kali lebih besar untuk menggunakan kontrasepsi dibandingkan dengan WUS yang berstatus belum kawin dengan nilai variabel lain konstan. Sedangkan wanita usia subur (WUS) yang berstatus kawin di Provinsi Jawa Timur memiliki kecenderungan 696.397 kali lebih besar untuk menggunakan kontrasepsi dibandingkan dengan WUS yang berstatus belum kawin dengan nilai variabel lain konstan.

b. Pada kategori hidup bersama, nilai odds ratio untuk Provinsi Nusa Tenggara Timur adalah 37.974. Artinya, wanita usia subur (WUS) yang berstatus hidup bersama di Provinsi Nusa Tenggara Timur memiliki kecenderungan 37.974 kali lebih besar untuk menggunakan kontrasepsi dibandingkan dengan WUS yang berstatus belum kawin dengan nilai variabel lain konstan. Sedangkan wanita usia subur (WUS) yang berstatus hidup bersama di Provinsi Jawa Timur tidak ada.

c. Pada kategori cerai mati, nilai odds ratio untuk Provinsi Nusa Tenggara Timur dan Jawa Timur masing-masing adalah 31.822 dan 373.961. Artinya, wanita usia subur (WUS) yang berstatus cerai mati di Provinsi Nusa Tenggara Timur memiliki kecenderungan 31.822 kali lebih besar untuk menggunakan kontrasepsi dibandingkan dengan WUS yang berstatus belum kawin dengan nilai variabel lain konstan. Sedangkan wanita usia subur (WUS) yang berstatus cerai mati di Provinsi Jawa Timur memiliki kecenderungan 373.961 kali lebih besar untuk menggunakan kontrasepsi dibandingkan dengan WUS yang berstatus belum kawin dengan nilai variabel lain konstan.

d. Pada kategori cerai hidup, nilai odds ratio untuk Provinsi Nusa Tenggara Timur dan Jawa Timur masing-masing adalah 39.887 dan 268.553. Artinya, wanita usia subur (WUS) yang berstatus cerai hidup di Provinsi Nusa Tenggara Timur memiliki kecenderungan 39.887 kali lebih besar untuk menggunakan kontrasepsi dibandingkan dengan WUS yang berstatus belum kawin dengan nilai variabel lain konstan. Sedangkan wanita usia subur (WUS) yang berstatus cerai hidup di Provinsi Jawa Timur memiliki kecenderungan 268.553 kali lebih besar untuk menggunakan kontrasepsi dibandingkan dengan WUS yang berstatus belum kawin dengan nilai variabel lain konstan. 
e. Pada kategori berpisah, nilai odds ratio untuk Provinsi Nusa Tenggara Timur dan Jawa Timur masing-masing adalah 7.091 dan 700.145. Artinya, wanita usia subur (WUS) yang berstatus berpisah di Provinsi Nusa Tenggara Timur memiliki kecenderungan 7.091 kali lebih besar untuk menggunakan kontrasepsi dibandingkan dengan WUS yang berstatus belum kawin dengan nilai variabel lain konstan. Sedangkan wanita usia subur (WUS) yang berstatus berpisah di Provinsi Jawa Timur memiliki kecenderungan 700.145 kali lebih besar untuk menggunakan kontrasepsi dibandingkan dengan WUS yang berstatus belum kawin dengan nilai variabel lain konstan.

2. Jumlah anak yang pernah dilahirkan

Nilai odds ratio dari variabel jumlah anak yang dilahirkan di Provinsi Nusa Tenggara Timur dan Jawa Timur berturut-turut adalah 0.176 dan 0.171. Artinya wanita usia subur (WUS) di Provinsi Nusa Tenggara Timur yang memiliki anak maksimal dua memiliki kecenderungan 0.176 kali lebih kecil untuk menggunakan kontrasepsi dibandingkan dengan WUS yang memiliki anak lebih dari dua dengan nilai variabel lain konstan. Sedangkan, wanita usia subur (WUS) di Provinsi Nusa Tenggara Timur yang memiliki anak maksimal dua memiliki kecenderungan 0.171 kali lebih kecil untuk menggunakan kontrasepsi dibandingkan dengan WUS yang memiliki anak lebih dari dua dengan nilai variabel lain konstan.

\section{Status Pekerjaan}

Nilai odds ratio dari variabel status pekerjaan adalah:

a. Pada kategori bekerja di pertanian, nilai odds ratio untuk Provinsi Jawa Timur adalah 0.629. Artinya, wanita usia subur (WUS) yang bekerja di pertanian memiliki kecenderungan 0.629 kali lebih kecil untuk menggunakan kontrasepsi dibandingkan dengan WUS yang tidak bekerja dengan nilai variabel lain konstan.

b. Pada kategori bekerja di non pertanian, nilai odds ratio untuk Provinsi Jawa Timur adalah 0.651 . Artinya, wanita usia subur (WUS) yang bekerja di non pertanian memiliki kecenderungan 0.651 kali lebih kecil untuk menggunakan kontrasepsi dibandingkan dengan WUS yang tidak bekerja dengan nilai variabel lain konstan.

\section{KESIMPULAN DAN SARAN}

\section{Kesimpulan}

Berdasarkan analisis dan pembahasan di atas, kesimpulan yang dapat diambil dari penelitian ini adalah pada Provinsi Nusa Tenggara Timur, persentase wanita usia subur (WUS) yang menggunakan kontrasepsi lebih kecil dibandingkan yang tidak menggunakan kontrasepsi. Sebaliknya, pada Provinsi Jawa Timur, persentase wanita usia subur (WUS) yang menggunakan kontrasepsi lebih besar dibandingkan yang tidak menggunakan kontrasepsi. Secara umum, baik di Provinsi Nusa Tenggara Timur maupun di Provinsi Jawa Timur, sebagian besar wanita usia subur yang menggunakan kontrasepsi adalah WUS yang berumur 35-39 tahun berstatus kawin dan bekerja di pertanian, memiliki anak lebih dari dua, serta pendidikan terakhirnya SD/sederajat. Dengan kata lain, tidak terdapat perbedaan karakteristik diantara kedua provinsi dengan TFR tertinggi dan terendah tersebut.

Berdasarkan hasil pengujian statistik dengan metode regresi logistik biner, faktor-faktor sosial demografi yang secara signifikan berpengaruh terhadap status penggunaan kontrasepsi pada wanita usia subur (WUS) di Provinsi Jawa Timur adalah usia, status perkawinan, status pekerjaan, jumlah anak yang pernah dilahirkan, dan pendidikan terakhir. Sedangkan di Provinsi Nusa Tenggara Timur faktor-faktor sosial demografi yang secara signifikan berpengaruh terhadap status penggunaan kontrasepsi pada wanita usia subur (WUS) adalah usia, status perkawinan, jumlah anak yang pernah dilahirkan, dan pendidikan terakhir. 


\section{Saran}

Untuk penelitian-penelitian selanjutnya, perlu ditambahkan lagi faktor-faktor selain faktor sosial demografi seperti faktor pemberdayaan perempuan, akses terhadap informasi mengenai kontrasepsi, ekonomi, budaya, dan lainnya untuk menyempurnakan penelitian.

\section{UCAPAN TERIMA KASIH}

Terima kasih penulis ucapkan kepada semua pihak yang telah memberikan saran dan masukan sehingga penelitian ini dapat diselesaikan dengan baik.

\section{REFERENSI}

Asiimwe, John B., dkk. (2013). Socio-Demographic Factors Associated With Contraceptive Use Among Young Wome in Comparison with Older Women in Uganda. USAID 2013 No. 95

Badan Pusat Statistik. (2018). Survei Demografi dan Kesehatan Indonesia. Jakarta: Badan Pusat Statistik.

Gage, Anastasia J. (2014). Sexual Activity and Contraceptive Use: The Components of the Decisionmaking Process. Studies in Family Planning, Vol. 29, No. 2, Adolescent Reproductive Behavior in the Developing World (Jun, 1998).

Hameed, Waqas, et al.(2014). Women's Empowerment and Fertility : Policy Lesson. UN Population Division, Expert Paper No. 2013/2.

Hartanto, Hanafi. (1994). Keluarga Berencana dan Kontrasepsi. Jakarta: Pustaka Sinar Harapan.

Kasto. (1995). Hand Out Tehnik Demografi PND 111. Program Studi Kependudukan Fakultas Pasca Sarjana Universitas Gajah Mada, Yogyakarta.

Kidayi, Paulo L, et al. (2015). Determinants of Modern Contraceptive among Women of Reproductive Age in Tanzania: Evidence from Tanzania Demographic and Health Survey Data. Advanced in Sexual Medicine.

Misga, Nieken de. (2017). Pengaruh Pemberdayaan Perempuan dan Faktor Sosial Demografi Terhadap Pemakaian Kontrasepsi Modern WUS (15-49 Tahun) Kawin/Hidup Bersama di Indonesia. Jakarta: Sekolah Tinggi Ilmu Statistik.

Silastri, Novri. (2017). Pengaruh Jumlah Penduduk dan Pendapatan Domestik Regional Bruto (PDRB) Terhadap Kemiskinan di Kbupaten Kuantan Singingi. JOM Fekon, Vol. 4 No. 1 (Februari) 2017.

Sukhan, R. 2001. Faktor yang Berhubungan dengan Keikutsertaan Ibu Pus dalam Program KB Pada Suku Talang Mamak di Desa Seberial Indragiri Hulu Provinsi Riau Tahun 2000. Tesis Program Pascasarjana Ilmu Kesehatan Masyarakat Universitas Indonesia Depok.

United Nations. (1995). Report of International Conference on Population and Development. United Nations, Sales No. 95.XIII.18, A/CONF.171/13/Rev.1, ISSBN 92-1-151289-1. 